\title{
IMPLEMENTASI DISIPLIN DIRI DALAM PENDIDIKAN KRISTEN ERA POSTMODERNISME
}

\author{
Yen Chorina
}

\begin{abstract}
A series of various failures of the modern world. Many things are undeniable happening in society in an instant. Often the situation that arises is considered a joke that is no longer interpreted in its true meaning. Self-love is decreasing, regardless of one's existence and position. More and more inappropriate behavior is shown which is easily viral through the existing sophisticated media. Awareness of self-existence, self-love is very important to be played in the environment. So it is necessary to re-instill the attitude of postmodernism to overcome the generations that are decreasing in quantity.
\end{abstract}

\section{Keywords: Digital, self-discipline, Christian religious education, postmodernisme}

Abstrak

Serangkaian dengan berbagai kegagalan dunia modern. Banyak hal yang tidak dipungkiri terjadi dalam kalangan masyarakat dengan sekejap. Seringkali keadaan yang muncul dianggap sebagai lelucun yang tidak lagi dimaknai arti sesunggunya. Kecintaan terhadap diri sendiri semakin berkurang, dengan tidak memperdulikan keberadaan diri serta kedudukan. Semakin banyak kelakuan yang tidak semestinya dipertontonkan yang dengan muda terviralkan melalui media-media canggi yang ada. Kesadaran akan keberadaan diri, kecintaan diri sangtlah penting untuk diperankan dalam lingkungan. Sehingga perluh ditanamkan kembali sikap postmodernisme untuk mengatasi para generasi yang semakin menurun kuantitasnya.

Kata Kunci : Digital, Disiplin diri, Pendidikan agama Kristen , postmodernisme

\section{PENDAHULUAN}

Dalam kalangan dunia zaman digital sekarang ini. Seringkali manusia tidak menyadari keberadaannya. Dengan semakin meningkat suatu perubahan perkembang sehingga manusia melupakan dirinya atau sangat sulit menjadikan diri sendiri. Perubahan perkembang zaman menjadikan manusia kurang radikal. Manusia seringkali menggunakan kebebasannya sehingga tidak lagi memaknai sesuatu sesuai makna yang sebenarnya. Dengan berbagai 
keuntungan yang terjadi sebagai dampak perkembangan medernisasi sehingga manusia tidak lagi memikirkan manfaat dari setiap tindakan yang dilakukan. Beberapa aspek atau bidang pendidikan juga tidak lagi mengajarkan dan mementingkan makna dari pengajarannya. Sehingga perlu untuk menanamkan kembali dan melakukan sesuatu sesuai dengan makna yang sesungguhnya. Dengan perkembangan modernisasi sehingga manusia tidak lagi memikirkan jangka panjang dari setiap tindakan. Sehingga perlu untuk menananmkan kembali ajaran lokal yang akan membawa pada pemaknaan secara kritis. Dalam melakukan pemaknaan secara kritis kepada para generasi zaman digital sangatlah susah, tetapi harus dibentengi dengan semangat demi untuk menciptakan generasi yang berkualitas.

\section{Tujuan}

Dengan adanya penulisan ini memberikan pemahaman untuk memaknai sesuatu sesuai dengan perkembangan saman dengan menggunakan sistem kritis. Sebagai manusia harus kritis dalam merespon perkembangan yang ada sesuai dengan maknanya sendiri. Dan juga kembali dilakukan penanaman disiplin diri untuk bisa memaknai sesuatu dengan baik.

\section{Maksud:}

Dengan memaknai perkembangan zaman sesuai makna yang kritis akan memberikan suatu dampak yang baik. Baik secara individual pun secara universal.

\section{PEMBAHASAN}

\section{Dunia Digital}

Seringkali dengan perkembangan modernisasi yang mengarahkan masyarakat dalam konsep yang baik. Tetapi sadar atau tidak disadari memberikan suatu dampak yang memuncak pada hal yang merugikan baik secara individu pun secara universal. Dalam rana kehidupan masyarakat yang digerakan oleh perkembagan digitalisasi, sangat membutukan pembaharuan.

Dunia digitalisasi dengan menerapkan sistem serba cepat. Sangat memberikan kemudahan yang luar biasa bagi manusia. Baik dalam bidang teknologi, pengetahuan, ekonomi dan lain-lain. Aktivitas kehidupan manusia sangat terdukung dengan adanya perkembangan ini. Dimana manusia melakukan aktifitas, mengejar keinginana dengan sekejap. Tetapi sangat disayangakn bahwa realitanya memberikan pengaruh negative yang sangat memuncak. Dengan kehidupan yang serba cepat manusia dikoersi untuk mencapai suatu keinginan, tetapi tanpa disadari bahwa manusia tidak akan menacapi keinginan ketika 
tidak memaknai secara radikal. Bahkan dengan cara yang serba cepat manusia melakukan berbagai cara apapun untuk memuaskan keinginananya. Tetapi kenyataannya bahwa manusia kemudian mulai dan bahkan kehilanan pengendalian diri, serta tidak mampu lagi menahan diri karena tujuan untuk memuaskan kenikmatan. Dengan terbiasanya manusia menjalani realita kehidupan yang seba instan sehingga mereka tidak lagi memikirkan, dan mengenali dirinya dengan baik. Sehinga tantangan dan kesulitan yang dihadapi inginnya segera terselesaikan secara instan. Tetapi tanpa sadar bahwa dalam menyelesaikan berbagai kesulitan itu tidak harus secara instan.

Dengan semakin instannya sehingga manusia tidak menyadari bahwa kesulitan atau tantangan yang dihadapi malah semakin meningkat. Dampak dari setiap perkembangan yang ada diakui bahwa sangat mempermuda manusia tetapi tantangan atau kesulitannya juga sangat melebihi hasil instan ilmu manusia sendiri. Seperti halnya dalam rana pendidikan. Para generasi yang inginnnya serba instan membuat manusia tidak lagi menghasilkan kuantitas yang baik.

\section{Pendisiplinan Diri}

Dalam setiap usaha untuk menjadi pribadi-pribadi yang kuat kebanyakan orang berhasil dengan melakukan dengan menampakkan disiplin diri serta menampakkan kekuatan dari kemampuannya. Dan terkadang dari situ banyak orang yang mengapresiasi kesuksesan itu. Dengan usaha manusia melakukan usaha Umat manusia yang berbalik dengan menggunakan cara disiplin diri atau dengan keyakinan dirinya dalam menjalani perjalanan hidupnya. Manusia berusaha memperbaiki kehidupan mereka dengan memulai semakin mengembangkan keahlian-keahlian yang mereka miliki. Bahkan semakin mengembangkan spiritualitasnya.

Disiplin diri sama kaitannya dengan kontrol diri. Bahkan disiplin diri semakin mendorong manusia untuk meningkatkan mental, serta kedisiplinan spiritual. Bahkan disiplin diri dapat menyeimbangkan emosional dan fisik. Pendisiplinan diri yang dilakukan bukan berarti hudup dalam berbagai aturan serta keterbatasan yang membuat pemikiran menjadi sempit melainkan dengan semakin melatih diri untuk menjadi lebih kuat dan lebih baik. ${ }^{1}$ Disiplin diri dapat dilakuakan dengan metode menyelasaikan persoalan dengan kemampuan dan dengan harus bersusah payah. Juga dengan semakin menaikkan tantangan

\footnotetext{
${ }^{1}$ Yuri Megato,M.M. dan.Tarmizi, Pelayanan Konseling pada satuan pendidikan menengah (Jakarta: Grasindo,2011),25.
} 
kepada tingga yang lebih tinggi sehingga semakin kuat. Dan semakin menerapkan sikap disiplin maka semakin mengarah kepada kemudahan. Seperti tantangan yang dihadapi meskipun dipandan tidak mampu menghadapi tetapi dengan penerapan disiplin makan itu pasti bisa dihadapi bahkan sudah dianggap sebagai hal biasa.

\section{Pendidikan Kristen}

Dalam konteks pendidikan sering kali model pembelajaran dilakukan hanya dilakukan saja tanpa memikirkan manfaat atau motivasi yang baik bagi para pelajar ${ }^{2}$. Kegagalan yang sering dialami manusia dalam rana pendidikan adalah lebih kepada pengembangan kemitraan yang benar dengan sifat atas-bawa yang hasilnya mengacu pada konsep dilematik yang jarang dikatakan tidak jarang konflik. Dengan berdasar pada Alkitab yang menjadi acuan dari teladan Yesus Kristus ialah kasih. Sehingga dalam pendidikan Kristen harus dikembangan dalam hubungan kebersamaan, kerendahan, pelilaku dalam kesederhanaan,kedisiplinan diri, dalam rana pelayanan dan pengembangan yang dikaitkan satu sama lain ${ }^{3}$.

Dalam pendidikan Kristen dan berbagai pembelajaran Kristen lainnya sebisa mungkin membantu pelajar untuk menginterpretasikan penggambaran atau suatu keyakinan dan juga perluh mengevaluasi nilai-nilai ajaran alam dari lingkungan yang sesering mungin mempengaruhi budaya ${ }^{4}$

Seperti penerapan metode local yang dilakukan dalam menerapkan disiplin diri bagi para pelajar ,diterapkan pembelajaran-pembelajaran mandiri seperti partisipasi langsung, dikisahi, memandang, serta membiasakan. Sehingga dari kemandirian atau usaha anak memberikan peluang yang besar untuk mengenali dirinya serta mengalami sendiri keadaan yang terjadi sisekitannya. Dari penerapan metode-metode ini juga menjadikan anak menemukan dan membentuk karakter dalam dirinya ${ }^{5}$.

\section{Postmodernisme}

\footnotetext{
${ }^{2}$ Rannu Sanderan," Exemplary, Menemukenali kunci pendidikan iman bagi anak dalam keluarga dan pembelajaran agama di sekolah" ( Tana Toraja: STAKN Toraja,2016)

${ }^{3}$ Rannu Sanderan, "Disiplin Asketisme dan Harmoni Kontribusi Disiplin diri bagi Pengembangan Pendidikan Kristen" ( Tana Toraja: STAKN Toraja, 2021)

${ }^{4}$ Rannu Sanderan ," INTUISI:Pendalaman Gagasan Hans-George Gadamer tentang Intuisi sebagai Supralogika" Jurnal Ilmiah Religiosity Entitu Humanity ( Desember 2021) Vol.2,No. 2, ${ }^{5}$ Rannu Sanderan," Heuristik dalam pendidikan Karakter manusia Toraja Tradisional" Jurnal Teologi dan Pendidikan Krinten Kontekstual (Desember 2020) Vol.3,No.2
} 
Postmodernisme diartikan sebagai suatu interpretasi yang tak terbatas. Dengan pemahaman bahwa postmodernisme menganut relativitas dari realita plural. Postmodernisme bertujuan merombak segala yang telah direncanakan dalam modernisme dengan melakuakan kajian ulang ${ }^{6}$. Sehingga dalam dunia pendidikan postmodernisme sangat mendukung dalam penerapan disiplin diri terkhusus dalam pendidikan Kristen.

\section{KESIMPULAN}

Dengan semakin meningkatnya perkembangan ilmu pengetahuan dan teknologi. Sehingga manusia tidak lagi berjalan sesuai keadaan diri sehingga perlu penanaman disiplin diri. Dengan disiplin diri diterapkan dalam pendidikan Kriten dapat membantu manusia menghadapi berbagai tantangan dengan baik. Serta dengan disiplin diri manusia lebih kuat menghadapi dampak-dampak dari perkembangan modernisasi. Dalam rana pendidikan juga diperlukan penarapan prinsip postmodernisme dalam mendukung terealisasinya disiplin diri dengan efektif.

\section{SARAN}

Terbiasalah untuk mendisiplinkan diri. Kenali diri dan kembangkan potensi sesuai kemampuan.

"Johan Setiawan," Pemikiran Postmodernisme dan pandangannya terhadap ilmu pengetahuan" Jurnal Filsafat, (Februari 2018) Vol.28,No.1 


\section{DAFTAR PUSTAKA}

Megato ,Yuri,M.M. dan Tarmizi, Pelayanan Konseling pada satuan pendidikan menengah. Jakarta: Grasindo,2011.

Sanderan Rannu ," Exemplary, Menemukenali kunci pendidikan iman bagi anak dalam keluarga dan pembelajaran agama di sekolah". Tana Toraja : STAKN Toraja, 2016

Sanderan, Rannu,, "Disiplin Asketisme dan Harmoni Kontribusi Disiplin diri bagi Pengembangan Pendidikan Kristen" Tana Toraja : STAKN Toraja, 2021

Snaderan, Rannu ," INTUISI:Pendalaman Gagasan Hans-George Gadamer tentang Intuisi sebagai Supralogika” Jurnal Ilmiah Religiosity Entitu Humanity 2, no.2 ( Desember 2021)

Sanderan, Rannu," Heuristik dalam pendidikan Karakter manusia Toraja Tradisional” Jurnal Teologi dan Pendidikan Krinten Kontekstual 3, no.2 (Desember 2020)

Setiawan, Johan," Pemikiran Postmodernisme dan pandangannya terhadap ilmu pengetahuan" Jurnal Filsafat 28, no 1 (Februari 2018) 